\title{
ДЕЯКІ ПРОЦЕСУАЛЬНІ ОСОБЛИВОСТІ ВИЛУЧЕННЯ МАЙНА ПІД ЧАС ЗДІЙСНЕННЯ ОКРЕМИХ СЛІДЧИХ (РОЗШУКОВИХ) ДІЙ
}

Лісніченко Д. В.

Стаття присвячена аналізу процесуального порядку вилучення майна під час проведення обшуку та огляду. Визначено категорії майна, які можуть бути вилучені під час огляду та обшуку, та проаналізовано їх процесуальний статус. Звернено увагу на недосконалість норм, що регулюють порядок вилучення майна під час проведення слідчих (розшукових) дій, та запропоновані шляхи їх усунення. Розглянуті питання необхідності вилучення майна під час проведення слідчого експерименту та сформульовані моделі дій, які не будуть протирічити чинному законодавству. Обгрунтовано необхідність існування можливості добровільного надання потерпілим, свідком та іншими особами речей та документів слідчому та наведені приклади таких дій в інших країнах.

Ключові слова: вилучення майна, обшук, огляд, слідчий експеримент, отримання майна.

Статья посвящена анализу процессуального порядка изъятия имущества при проведении обыска и осмотра. Определены категории имущества, которые могут быть извлечены при осмотре и обыске, и проанализирован их процессуальный статус. Обращено внимание на несовершенство норм, регулирующих порядок изъятия имущества при проведении следственных (розыскных) действий, и предложены пути их устранения. Рассмотрены вопросы необходимости изъятия имущества при проведении следственного эксперимента и сформулированы модели действий, которые не будут противоречить действующему законодательству. Обоснована необходимость существования возможности добровольного предоставления потерпевшим, свидетелем и другими лицами вещей и документов следователю, приведены примеры существования таких действий в других странах.

Ключевые слова: изъятие имущества, обыск, осмотр, следственный эксперимент, получение имущества.

The article is devoted to the analysis of the procedural procedure for seizure of property during the search and inspection. The difference between search and search is analyzed. The procedural procedure for examining a petition for a search was investigated. The categories of property that can be removed during inspection and search are identified and their procedural status is analyzed. Attention is drawn to the imperfection of the rules governing the seizure of property during investigative (search) actions. Proposed ways to eliminate these shortcomings. Specific features of the seizure of items not specified in the court search order are stated separately. Identified categories of things and documents that can be removed even if they are not specified in the search warrant.

Procedural procedure and peculiarities of property seizure during the review are analyzed. Attention is drawn to the cases of detection of things and documents that are relevant for criminal proceedings during such investigative (investigative) action as an investigative experiment. The position that the investigative experiment does not foresee the possibility of seizure

Лісніченко Д. В., 2019 of property is substantiated. Algorithms of actions are formulated and proposed, which will allow procedurally correct implementation of the property seizure, if it is found during the investigation experiment.

Attention was drawn to the existence of facts of voluntary transfer of property to the investigator. The investigative practice on the stated facts is analyzed, and the imperfection of the procedural registration of the facts of voluntary transfer of property is noted, which negatively reflects on the admissibility of them as evidence. The necessity of procedural regulation of such action as separate investigative (investigative) action has been proved. The legislation of foreign countries, where such action exists, is analyzed. This action will allow the victim to fully exercise their procedural rights.

It also substantiates the necessity of introducing a mechanism for requiring investigators for items that are necessary for conducting investigative (investigative) actions. Examples of such mechanisms exist in the laws of different countries.

Key words: seizure of property, search, examination, investigative experiment, obtaining property.

Здебільшого вилучення майна під час досудового розслідування здійснюється з метою збирання доказів, оскільки для забезпечення конфіскації, спеціальної конфіскації та забезпечення цивільного позову застосовується такий захід забезпечення кримінального провадження, як арешт майна.

У юридичній літературі обґрунтовано зазначається, що серед способів збирання доказів слідчі (розшукові) дії мають найбільшу вагу [1, с. 249]. Крім цього, слідчі (розшукові) дії $\epsilon$ однією з основних кримінальних процесуальних форм вилучення майна.

Дослідженню інституту слідчих дій приділено багато уваги як вітчизняними, так і закордонними ученими-процесуалістами. Наукові праці вчених Ю.П. Аленіна, В.П. Бахіна, Ю.М. Білозерова, В.І. Зажицького, Н.С. Карпова, В.Ж. Кукліна, О.М. Ларіна, І.М. Лузгіна, Є.Д. Лук'янчикова, В.Т. Маляренка, О.Р. Михайленка, М.М. Михеєнка, В.Т. Нора, Л.І. Петрухіна, Д.П. Письменного, О.П. Рижакова, С.М. Стахівського, М.С. Строговича,Л.Д. Удалової, А.П. Черненка, С.О. Шейфера, В.Ю. Шепітька, М.Є. Шумили та інших внесли значний вклад у розуміння слідчих дій, а також у шляхи їх розвитку та еволюції. Однак через надзвичайну значимість слідчих дій для кримінального процесу, різні підходи та наявність різних думок залишили цілу низку дискусійних аспектів, у тому числі стосовно вилучення майна під час проведення слідчих дій.

Глава 20 КПК України присвячена слідчим (розшуковим) діям. Аналіз цієї глави, яка містить у собі перелік та порядок застосування слідчих (розшукових) дій, дає змогу стверджувати, що слідчими (розшуковими) діями, процесуальний порядок проведення яких передбачає вилучення речей, документів (майна), є обшук та огляд [2]. 
3 позиції ефективного розслідування зауважимо, що як у минулому, так і нині обшук $є$ однією з найбільш ризикованих і водночас однією з найбільш плідних слідчих (розшукових) дій, що включає і вилучення майна. Адже майже жодне розслідування не може обійтися без обшуку з тієї простої причини, що саме обшук передбачає дії слідчого щодо пошуку або збору речових доказів [3, с. 16].

Водночас обшук та огляд мають суттєві відмінності. Так, огляд місця події може проводитись до моменту, 3 якого розпочинається кримінальне провадження (ч. 2 ст. 214 КПК України), тобто до моменту внесення відомостей до ЄРДР, а провадження обшуку допускається лише за наявності кримінального провадження.

Однією з основних відмінностей обшуку від огляду $\epsilon$ мета їх застосування. Так, в обшуку вона більш конкретна, але значно вужча за мету огляду, в ході якого акцентується увага на всебічному дослідженні, детальній фіксації як обстановки, навколишнього середовища, так і об'єкта, що оглядається, можливо, з подальшим його вилученням.

Деякі науковці зазначають, що відповідно до пункту 7 частини 3 статті 234 КПК України клопотання про обшукмаєміститивідомостіпро речі, документиабо осіб, яких планують відшукати. Тому що у разі задоволення клопотання про проведення обшуку без чіткого переліку об'єктів компетентні особи можуть визнати майже будь-яку річ, предмет, документ такими, що мають відношення до кримінального провадження, і вилучити їх, що $є$ загрозою безпідставного порушення прав, свобод та охоронюваних законом інтересів особи [4, с. 109].

Ми не можемо погодитись з такою позицію, оскільки слідчий чи прокурор у момент складання клопотання не можуть передбачити наявність всіх можливих речей та документів, які можуть знаходитись на місці проведення обшуку. Потрібно пам'ятати, що пошукова функція обшуку спрямована не лише на пошук заздалегідь ідентифікованої речі, а й на пошук інших предметів, що можуть знаходитись за місцем проведення обшуку. Оскільки обшук за своєю суттю $€$ несподіваною слідчою дією, то злочинець або інші заінтересовані особи після проведення обшуку та вилучення предметів, які вказані в ухвалі, усвідомлять необхідність знищення доказів, які слідчий, можливо, і виявив, але був позбавлений можливості їх вилучення. На наше переконання, наявність норми, яка б зобов'язувала слідчого, прокурора або уповноважену особу, яка здійснює обшук, вилучати виключно речі і документи, які зазначені в ухвалі, безпідставно звузить процесуальні можливості органів досудового розслідування.

Відповідно до ч. 7 ст. 236 КпК України під час обшуку вилученню підлягають:

1) речі, які вказані в ухвалі слідчого судді про дозвіл на обшук і для виявлення яких проводиться ця слідча (розшукова) дія;

2) речі, вилучені законом з обігу, незалежно від їх відношення до кримінального провадження;

3) речі, що не входять до переліку, щодо якого прямо надано дозвіл на відшукання в ухвалі про дозвіл на проведення обшуку, та не належать до предметів, які вилучені законом з обігу;

4) речі, які мають значення для кримінального провадження та вилучені під час особистого обшуку осіб, які перебувають у приміщенні під час проведення обшуку.
Що стосується першої категорії, то це речі та документи, які на переконання слідчого, прокурора беззаперечно мають значення для кримінального провадження, і саме на пошук яких береться дозвіл на проведення обшуку.

Що стосується другої категорії, а саме речей, заборонених законом в обігу (наркотичних засобів, психотропних речовин, зброї, боєприпасів, вибухівки та ін.), то випадки їх виявлення $\epsilon$ також непоодинокими. Цілком логічною $є$ вимога закону щодо вилучення таких речей і предметів та невіднесення останніх до категорії тимчасово вилученого майна, оскільки вони (наприклад, наркотичні речовини, психотропні засоби, зброя, вибухівка, боєприпаси та ін.) апріорі не можуть кому-небудь належати на праві власності. Процедура призначення експертизи та час на іï проведення позбавляють органи досудового розслідування у встановлений законом строк для подачі клопотання про накладення арешту на тимчасово вилучене майно визначити та процесуально закріпити факт того, що вилучений об'єкт належить до предмета, забороненого законом в обігу. Отже, де-юре закон не відносить предмети, заборонені законом в обігу, до тимчасово вилученого майна та не вимагає від органів досудового розслідування звертатись до суду з проханням про накладення арешту, а де-факто слідчий, прокурор, будучи дуже обмежені часом подання клопотання про накладення арешту, змушені у встановлений законом строк звертатись $з$ клопотанням про таке накладення арешту, навіть коли об'єктом виступає предмет, який заборонений законом в обігу.

Окремо потрібно зупинитись на категорії речей та документів, що не входять до переліку, щодо якого прямо надано дозвіл на відшукання в ухвалі про дозвіл на проведення обшуку, та не належать до предметів, які вилучені законом з обігу. Дуже часто в ході проведення обшуку слідчий, прокурор, який здійснює вказану слідчу дію, виявляє предмети чи документи, які не входять у перелік зазначених в ухвалі, але мають велике значення для встановлення обставин скоєння злочину. Це логічно, оскільки слідчий, прокурор, який здійснює розслідування, на момент складання клопотання на дозвіл на проведення обшуку не володіє інформацією (знанням) про повний перелік об'єктів, що стосуються обставин скоєння злочину, тому позбавлений можливості зазначити в клопотанні весь перелік таких речей. У зв'язку з чим вважаємо логічною можливість вилучення таких речей слідчим. Крім цього, доволі частими $\epsilon$ випадки виявлення під час обшуку речей та документів, які свідчать про скоєння інших злочинів. Можливість їх вилучення забезпечує виконання завдань кримінального провадження, а саме забезпечення швидкого, повного та неупередженого розслідування і судового розгляду з тим, щоб кожний, хто вчинив кримінальне правопорушення, був притягнутий до відповідальності в міру своєї вини, жоден невинуватий не був обвинувачений або засуджений, жодна особа не була піддана необґрунтованому процесуальному примусу $\mathrm{i}$ щоб до кожного учасника кримінального провадження була застосована належна правова процедура (ст. 2 КПК України).

Внаслідок аналізу норм чинного КПК України ми дійшли висновку, що речі і документи можуть бути вилучені під час проведення обшуку, не будучи зазна- 
ченими у відповідній ухвалі слідчого судді за наявності достатніх підстав, передбачених ч. 2 ст. 167 КПК України, а саме:

1) підшукані, виготовлені, пристосовані чи використані як засоби чи знаряддя вчинення кримінального правопорушення та (або) зберегли на собі його сліди;

2) були призначені (використані) для схиляння особи до вчинення кримінального правопорушення, фінансування та/або матеріального забезпечення кримінального правопорушення або винагороди за його вчинення;

3) $\epsilon$ предметом кримінального правопорушення;

4) одержані внаслідок учинення кримінального правопорушення та/або $є$ доходами від них, а також майно, на яке їх було повністю або частково перетворено.

що стосується огляду, то багато в чому механізми вилучення подібні до обшуку. Згідно з ч. 1 ст. 237 КПК України огляд здійснюють з метою виявлення та фіксації відомостей щодо обставин учинення кримінального правопорушення. Законодавець передбачив такі види огляду: місцевості, приміщення, речей та документів.

Говорячи про критерії речей і документів, які можливо вилучити в ході огляду, законодавець зазначив такі:

1) речі й документи, які мають значення для кримінального провадження;

2) речі, вилучені з обігу (частина 5 статті 237 КПК України).

На відміну від обшуку, під час огляду тимчасово вилученим майном вважають усі речі й документи, які мають значення для кримінального провадження, крім тих, які заборонені законом в обігу (частина 7 статті 237 КПК України).

Відповідно до ч. 5 ст. 237 КПК України всі речі, вилучені під час проведення огляду, підлягають негайному огляду й опечатуванню із завіренням підписами осіб, які брали участь у проведенні огляду. Ст. 236 КПК України, яка врегульовує процесуальний порядок проведення обшуку, такої вимоги не містить, водночас наведені у ч. 5 ст. 237 КПК України вимоги, на нашу думку, мають бути поширені і на речі, що вилучені під час проведення обшуку.

У разі якщо огляд речей і документів, які були вилучені, на місці здійснити неможливо або ускладнений, то їх тимчасово опечатують і зберігають у такому вигляді доти, доки не буде здійснено їх остаточні огляд й опечатування (частина 5 статті 237 КПК України).

Деякі науковці вважають, що вилучення речей (майна), документів може мати місце не тільки під час обшуку, огляду та затримання. Зокрема, до таких дій повною мірою може належати слідчий експеримент. Ми не можемо погодитись з такою думкою, оскільки переконані, що кожній процесуальній дії, в тому числі і слідчій (розшуковій), притаманний виключний перелік інструментів, елементів, тактичних прийомів та засобів, властивих саме цій процесуальній дії. Відповідно до ст.ст. 168, 208, 234, 236, 237 КПК України вилучення майна можливе лише у разі обшуку, огляду та затримання.

Однак зазначена проблема має місце в практичній діяльності. На підставі вивчення слідчої практики та власного досвіду в правоохоронних органах ми дійшли висновку, що непоодинокими $є$ випадки, коли в ході проведення слідчого експерименту виявляються предмети, які мають значення для кримінального провадження. Під час дослідження матеріалів кримінальних проваджень траплялись випадки, коли в рамках проведення слідчого експерименту виявлялись предмети, які мали значення для кримінального провадження та вилучались у рамках вказаної слідчої (розшукової) дії, про що вносились відповідні відомості до протоколу слідчого експерименту. Ми вважаємо таку практику помилковою, оскільки слідчий експеримент у структурі слідчих (розшукових) дій переслідує інші завдання. Слідчий експеримент не розцінюється як процесуальна дія, спрямована на вилучення майна, про що вказує і стаття 240 КПК України «Слідчий експеримент», в якій відсутні норми, що передбачають таке вилучення.

Ми вважаємо, що вилучення предметів у рамках проведення слідчого експерименту не відповідає вимогам чинного КПК. На нашу думку, оптимальним та таким, що відповідає нормам чинного законодавства, $є$ проведення вилучення виявленого предмета в рамках огляду місцевості. Отже, якщо під час слідчого експерименту був виявлений предмет, що має значення для кримінального провадження, слідчий зупиняє проведення слідчого експерименту та оголошує, що буде проведений огляд місцевості. Учасниками огляду виступають учасники слідчого експерименту. Також понятими під час огляду можуть бути присутні поняті під час слідчого експерименту, на що немає прямої заборони закону (тобто участь понятих у декількох слідчих (розшукових) діях). У рамках огляду здійснюється вилучення предмета у відповідності до ст.ст. 223, 237 КПК України. Надалі слідчий оголошує про продовження слідчого експерименту. У разі неможливості переривання слідчого експерименту за наявності постанови про створення слідчої групи, відразу в ході проведення слідчого експерименту, інший слідчий, що входить до зазначеної слідчої групи, може проводити огляд місцевості. Зазначений алгоритм дій, на нашу думку, не суперечить КПК України, відповідає завданням слідчих (розшукових) дій та не дасть підстави ставити під сумнів допустимість отриманих доказів у результаті такого вилучення.

На нашу думку, окремо варто сказати про можливість отримання майна органами досудового розслідування під час кримінального провадження. Частина 2 статті 93 КПК України зазначає, що сторона обвинувачення здійснює збирання доказів шляхом проведення слідчих (розшукових) та негласних слідчих (розшукових) дій, витребування та отримання від органів державної влади, органів місцевого самоврядування, підприємств, установ та організацій, службових та фізичних осіб речей, документів, відомостей, висновків експертів, висновків ревізій та актів перевірок, проведення інших процесуальних дій [2].

У зв'язку з цим збирання доказів стороною обвинувачення шляхом проведення слідчих (розшукових) дій, негласних слідчих (розшукових) дій, витребування (тимчасовий доступ до речей та документів) цілковито залежить від ініціативи цієї сторони, тобто слідчого чи прокурора. Сторона обвинувачення ініціює початок застосування тієї чи іншої форми збирання доказів. На нашу думку, такий стан справ не в повному обсязі відповідає інтересам держави та суспільства на теренах боротьби зі злочинністю. Така безальтернативність нівелює прагнення громадянського суспільства до комунікації з правоохоронними органами. Позбавляє можливості зафіксувати свою правову позицію. 
Варто наголосити, що в практичній діяльності мають місце непоодинокі факти, коли потерпілий чи свідок бажають надати якісь докази щодо кримінального провадження, і це не дивно. Потерпілий, як ніхто інший, зацікавлений у відновленні своїх порушених прав і здебільшого намагається всіляко допомагати правоохоронним органам. Відсутність механізму надання доказів потерпілим фактично позбавляє потерпілого його права на відстоювання своїх інтересів та можливості сприяння органам досудового розслідування у відновленні порушених прав, що, на нашу думку, є недопустимим.

На практиці за наявності таких фактів здебільшого органи досудового розслідування застосовують такий алгоритм. Органи досудового розслідування відбирають у потерпілого заяву про бажання видачі певної речі чи документа, а надалі здійснюють огляд указаних предметів зі складанням протоколу огляду предмета з фіксацією в ньому інформації, що предмети, які підлягають огляду, видані конкретною особою. У такому алгоритмі немає порушень чинного законодавства, але, вважаємо, у разі таких дій залишається процесуально не зафіксованим сам факт передачі речей і документів, що може стати перешкодою для визнання речей і документів допустимими доказами в суді. Своєю чергою для недопущення таких фактів органи досудового розслідування у разі виявлення бажання особи видати певні речі і документи, які мають вагоме значення для кримінального провадження, застосовують такий захід, як тимчасовий доступ до речей і документів, що, по-перше, не зовсім відповідає правовій природі вказаного заходу, а по-друге, вимагає витрати часу на дотримання процедури здійснення.

Крім того, потрібно зазначити, що особою, яка матиме бажання сприяти досудовому розслідуванню, може бути не лише потерпілий. Це може бути особа, яка має певні зв'язки з потерпілим, наприклад родинні, трудові, товариські, і бажає допомогти у відновленні порушених прав потерпілого. Вона може мати лише статус свідка.

Також як і у разі застосування витребування речей за допомогою такого способу збирання доказів (речей, документів) стороною обвинувачення можуть бути отримані від органів державної влади, органів місцевого самоврядування, підприємств, установ та організацій, службових і фізичних осіб будь-які речі, які мають значення для встановлення обставин кримінального правопорушення, за винятком речей, вилучених законом з обігу.

У працях науковців, опублікованих до набрання чинності КПК України 2012 року, обґрунтовувалася доцільність відображення факту подання доказів у самостійному протоколі, який пропонувалося іменувати «протоколом подання доказів», «протоколом добровільної видачі доказів» та ін. Ми вважаємо, що $з$ прийняттям чинного КПК України необхідність у зазначеній процесуальній дії нікуди не ділась та досі $\epsilon$ нагальною.
На нашу думку, вказана проблема на достатньому рівні вирішена в кримінально-процесуальному законодавстві Республіки Казахстан. КПК Казахстану містить статтю 259 «Надання особі, яка здійснює досудове розслідування, предметів і документів з ініціативи осіб, які ними володіють», в якій зазначено:

«Сторони, а також інші особи, керівники та інші посадові особи підприємств, установ, організацій вправі надавати особі, яка здійснює досудове розслідування, предмети і документи, які на їхню думку можуть мати значення для справи.

Особа, яка здійснює досудове розслідування, зобов'язана оглянути наданий предмет, документ за правилами і прийняти його, якщо $є$ підстави вважати, що предмет або документ має або в подальшому може мати значення для справи. Предмети, документи, які не мають значення для такої справи, але вилучені з обігу, також мають бути прийняті.

У разі надання предмета, документа, що не має значення для справи і не вилученого з обігу, особа, яка здійснює досудове розслідування, негайно після огляду повертає предмет, документ за належністю» [5].

Ми вважаємо, що подібного механізму вкрай не вистачає національному законодавству. Його запровадження не порушує жодних прав, оскільки це добровільна дія, без ознак примусу. Також наявність такого механізму призведе до оптимізації досудового розслідування, дасть змогу більш раціонально використовувати час. Ще одним важливим, на нашу думку, аспектом $€$ те, що надання суспільству ініціативи в сприянні боротьбі зі злочинністю матиме виховний характер на шляху розвитку громадянського суспільства та налагоджуватиме взаємодію між суспільством та правоохоронними органами.

\section{Література}

1. Кримінальний процесуальний кодекс України : науково-практичний коментар / За заг. ред. В.Г. Гончаренка, В.Т. Нора, М.Є. Шумила. Київ : Юстініан, 2012. 1224 с., с. 249.

2. Кримінальний процесуальний кодекс України : Закон України від 13.04.2012 р. № 4651-VI: (станом на 11.01.2019 р.). URL: https://zakon.rada.gov.ua/ go/4651-17 (дата звернення: 20.08.2019).

3. Благодир А.А. Застосування примусу під час провадження слідчих дій : автореф. дис. ... канд. юрид. наук : 12.00.09. Київ, НУВС. 2009. 20 с.

4. Моргун Н.С. Засада недоторканності права власності у досудовому кримінальному провадженні : дис. ... канд. юрид. наук. Київ, 2015. 213 с.

5. Уголовно-процессуальный кодекс Республики Казахстан. URL: https://online.zakon.kz/Document/?doc_ id=31575852 (дата звернення: 18.08.2019).

Лісніченко Д. В., старший науковий співробітник науково-дослідної лабораторії з проблемних питань кримінального аналізу

Одеського державного університету внутрішніх справ 